\title{
Suitability Analysis of Office Building Design against Maintenance Cost (Case Study of Serayu Opak River Basin Organization, Yogyakarta Province)
}

\author{
Mario Puji Hersanto \\ Ministry of Public Works and Housing, Central Jakarta, INDONESIA \\ mariopujihersanto@gmail.com
}

Ashar Saputra

Department of Civil and Environmental Engineering, Universitas Gadjah Mada, Yogyakarta, INDONESIA saputra@ugm.ac.id

Suprapto Siswokarto

Department of Civil and Environmental Engineering, Universitas Gadjah Mada, Yogyakarta, INDONESIA

suprapto.siswosukarto@ugm.ac.id

\begin{abstract}
This study aims to determine the effect of building design's inaccuracy against the cost of maintenance, by taking the research in Serayu Opak River Basin Organization, Water Resources Field and Water Resources Management Center in Yogyakarta Special Region. The first step is to analyze the inaccuracy of building design based on the result of interview and observation during field survey. The second step is to analyze the cost of building maintenance. The third step is to analyze the maintenance costs used to minimize the effects of the inaccurate design of the building. The result shows the inaccuracy of building design in the form of the use of clear glass without coated glass film and the absence of heat insulator on the roof of the building cause the room to become hot. The installation of rain gutters without vertical pipes, toilet facilities in the entire building is not yet complete, inadequate accessibility for persons with disabilities, and inadequate corridor design. There is a small portion of the maintenance budget used for reducing the impact of building design's inaccuracy, so it can be concluded that the design of the building is less meet the requirements of the Government regulations.
\end{abstract}

Keywords: Inaccuracy of building design, maintenance budget, Government regulations.

\section{INTRODUCTION}

This research wanted to know the relation of building design against maintenance cost. The buildings that will be used as research objects are located in Solo Km.6 Street, Caturtunggal, Sleman District, Yogyakarta Special Region and consists of 4 buildings, namely Serayu Opak River Basin Organization (SORBO) building, PKSDA building, PJSA and Water Resources Field (WRF) building, and Water Resources Management Center (WRMC) building.

The data required in this study include primary data and secondary data. Primary data were obtained in two ways, field survey, and interview of managers and users of the building. Data were collected by recording and photo documentation. Secondary data required in the form of floor plans and specifications, organizational structure and details activities of building maintenance costs per year during 2012 2016.
Similar research was conducted by Ervianto (2007) which studied about the building maintenance study (case study of campus building). The purpose of this study is to find out the program of building maintenance and its facilities that have been running and determine the estimated cost of maintenance. The results of study indicate that the cost is needed every year is big enough, about $2.70 \%$ of routine expenditure, with the largest percentage for cleaning service activities that is equal to $71.23 \%$ of total maintenance costs.

\section{METHODS}

\subsection{Building Design Analysis}

Office building design analysis based on the provisions contained in the book Architects Data Edition 33 Volume 1 (1996) and Volume 2 (2002) by Ernst Neufert and using four basic laws, namely:

a) Government Regulation (2005) No. 36/2005 on the Implementation of Law Number 28 Year 2002 about Building. 
b) Regulation of the Minister of Public Works (2007) No. 45/PRT/M/2007 Year 2007 on Technical Guidance of State Building Construction.

c) Guidance for Planning and Operation of Parking Facilities 1998. (Directorate General of Land Transportation, 1998)

d) Standard of Public Toilets Indonesia Year 2004. (Ministry of Culture and Tourism, 2004)

\subsection{Building Maintenance Cost Analysis}

Building maintenance cost analysis using 5 Regulation of the Minister of Finance on Input Cost Standard, namely:

a) Regulation of the Minister of Finance (2011) Number 84/PMK.02/2011 on Standard Cost Input of Fiscal Year 2012.

b) Regulation of the Minister of Finance (2012) Number 37/PMK.02/2012 on Standard Cost Input of Fiscal Year 2013.

c) Regulation of the Minister of Finance (2013) No. 72/PMK.02/2013 on Standard Cost Input of Fiscal Year 2014.

d) Regulation of the Minister of Finance (2014) No.53/PMK.02/2014 on Standard Cost Input of Fiscal Year 2015.

e) Regulation of the Minister of Finance (2015) No.65/PMK.02/2015 on Standard Cost Input of Fiscal Year 2016.

\subsection{Analysis of the Influence of Building Design} Inaccuracy against Maintenance Costs

This analysis serves to determine the cost of maintenance used to minimize the effects of building design inaccuracy.

\section{RESULTS}

\subsection{Building Design Inaccuracy Analysis}

\subsubsection{Inaccuracy Design Cause the room became hot}

a) The heavy use of transparent glass on the side of the building

Buildings that became the object of research using a lot of clear glass as a cover of the building so that the rooms are exposed to the sun's heat during the afternoon, so the room becomes hot and glare. The hot and glare room is not suitable for the comfort requirements of the building contained in Government Regulation No. 36/2005 on the Implementation of Law Number 28 Year 2002 regarding Building. Image of the exposed part of the building can be seen in Figure 1.

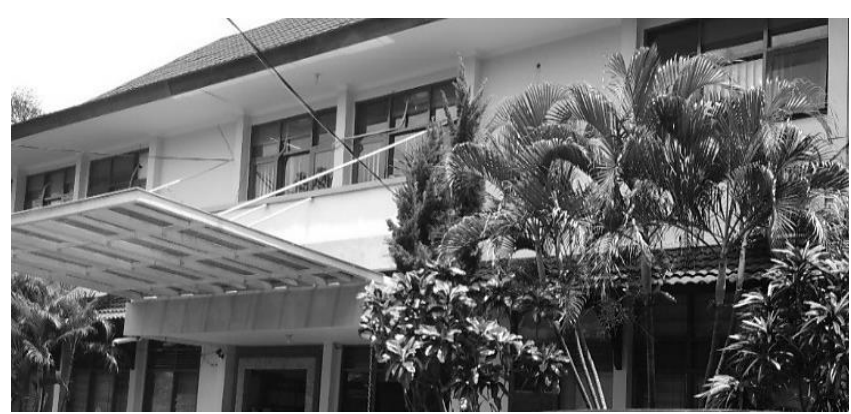

Figure 1. The side of the Serayu Opak River Basin Organization building.

The glass used in the building is clear glass $3 \mathrm{~mm}$. Clear glass has the nature of continuing $90 \%$ of visible waves and $85 \%$ of the sun's radiation into the room thus making the room become glare and room temperature increases (Soegijanto, 1998). To reduce the heat and the glare in the room, the best solution that can be done is to install window film. In order not to reduce the aesthetics should use a clear window film with a large TSER value on building glass (Astuti, 2017).

b) The absence of heat insulators on the roof

The building was designed without using heat insulator on the roof so that the heat from sunlight that enters through the roof will impact on the heat of the room below. To reduce the heat, the building managers should use heat insulators made from polyurethane foam to inhibit the rate of heat transfer from outside into the building. Polyurethane foam is the most effective heat insulator material, especially in buildings which are quite difficult to be given sheetsshaped insulators because polyurethane foam is powder-shaped and mounted in spray form so it can reach a difficult position on the roof of the building (Melati, 2015).

\subsubsection{Inaccuracy Design of Rainwater Gutters}

In Figure 2, we can see the design of less suitable gutters because the outlet pipe (funnel) is located at an altitude of $\pm 7 \mathrm{~m}$ from the soil surface so that the rain flow from the roof will fall inappropriately in the rain drain. It should be on the gutters mounted vertical pipe to approach the sewer so that rainwater from the roof can be entirely wasted into the sewer. 


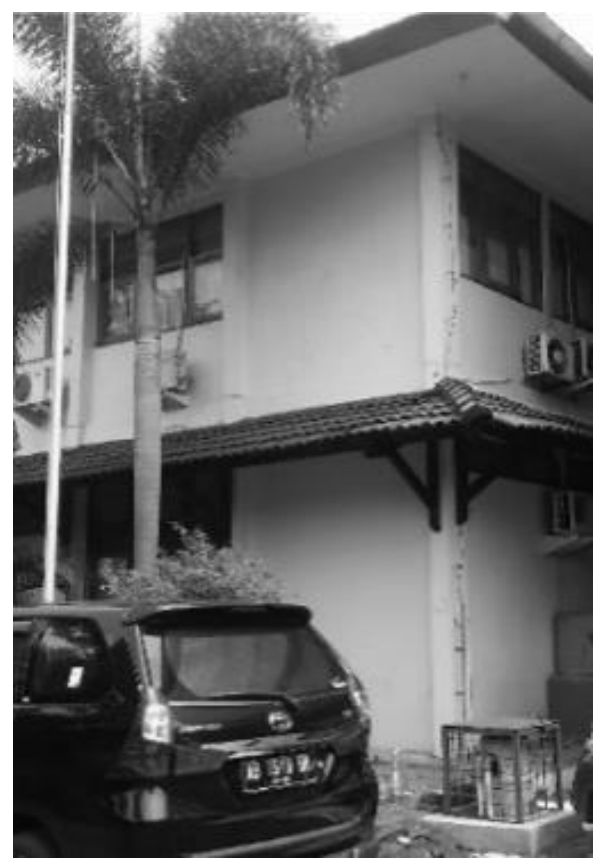

Figure 2. Rainwater gutters without vertical pipes at Serayu Opak River Basin Organization building.

\subsubsection{Inaccuracy Toilet Design}

a) The lack of sink layout

The sink position in Water Resource Management Centre (WRMC) building is not in accordance with Indonesian Public Toilet Standards (Figure 3) because it is installed in the corner and too close to the wall making it difficult for users to wash their hands and or faces.

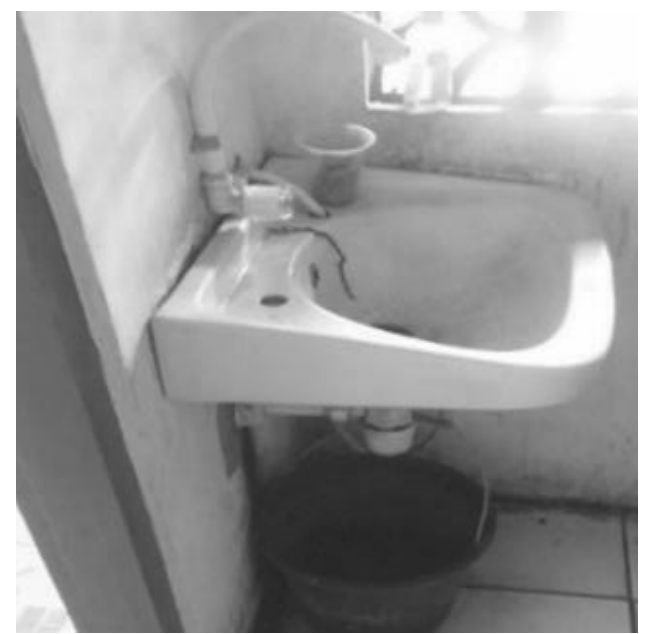

Figure 3. The location of the sink in the Water Resources Management Centre (WRMC) building.

The width of the sink room in the toilet room of the Serayu Opak River Basin Organization which is only $75 \mathrm{~cm}$ in size is not suitable for the recommended size in Indonesian Standard Public Toilet by $90 \mathrm{~cm}$. The sink room in the toilet of Serayu Opak River Basin Organization can be seen in Figure 4.

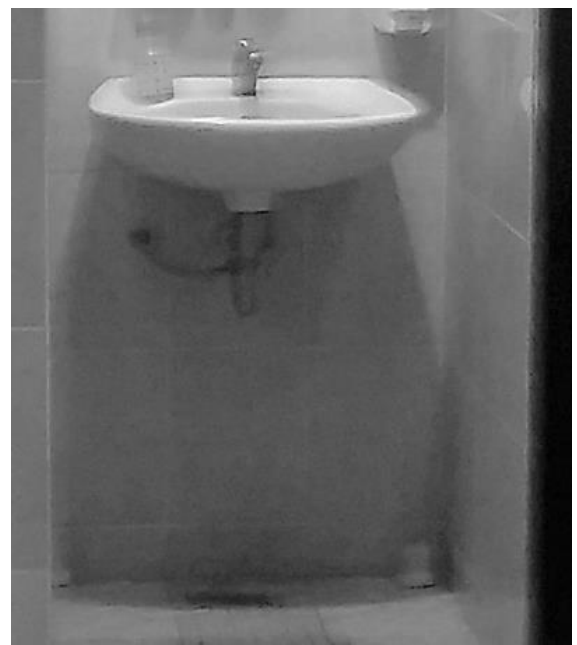

Figure 4. The sink room in the toilet of the Serayu Opak River Basin Organization building.

b) Less suitable for urinal location

The location of the urinal at the end of the toilet and facing directly into the corridor is less unsightly, especially when there are employees who use it to urinate (Figure 5).

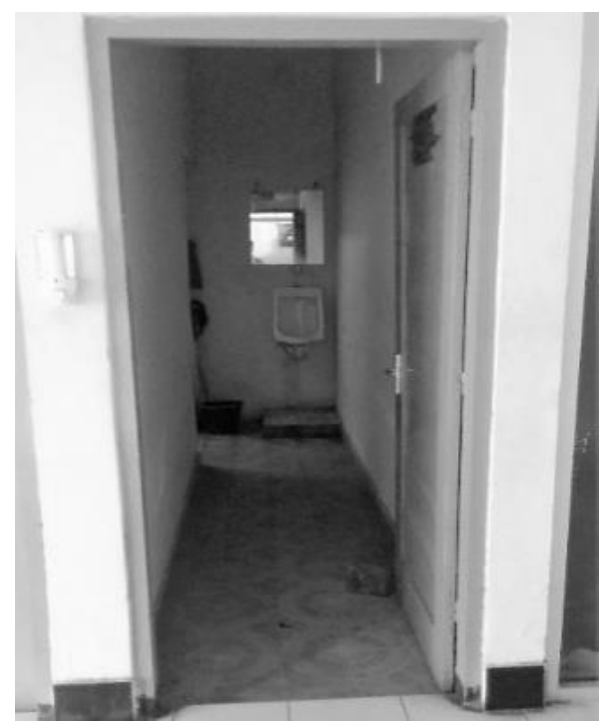

Figure 5. Location of the urinal in PJSA and Water Resources Field (WRF) building facing corridor.

c) Incomplete toilet facilities

The completeness of public toilets facilities in Serayu Opak River Basin Organization (SORBO) building, PKSDA building, PJSA and Water Resources Field (WRF) building, and Water Resources Management Center (WRMC) building can be seen in Table 1. 


\subsubsection{Inaccuracy Accessibility Design}

a) The absence of guiding block and Braille facilities around the building can reduce accessibility for the visually impaired.

b) There is a step on the access to the entrance and toilets. This makes it difficult for wheelchair users to enter the building without assistance as seen in Figure 6 and Figure 7. It should be at the entrance of the building made ram so that wheelchair users can enter the building with ease.

c) There is a parking lot of vehicles blocking access to the entrance. This is due to the absence of signs, parking borders, and information boards so that workers park vehicles freely as seen in Figure 8.

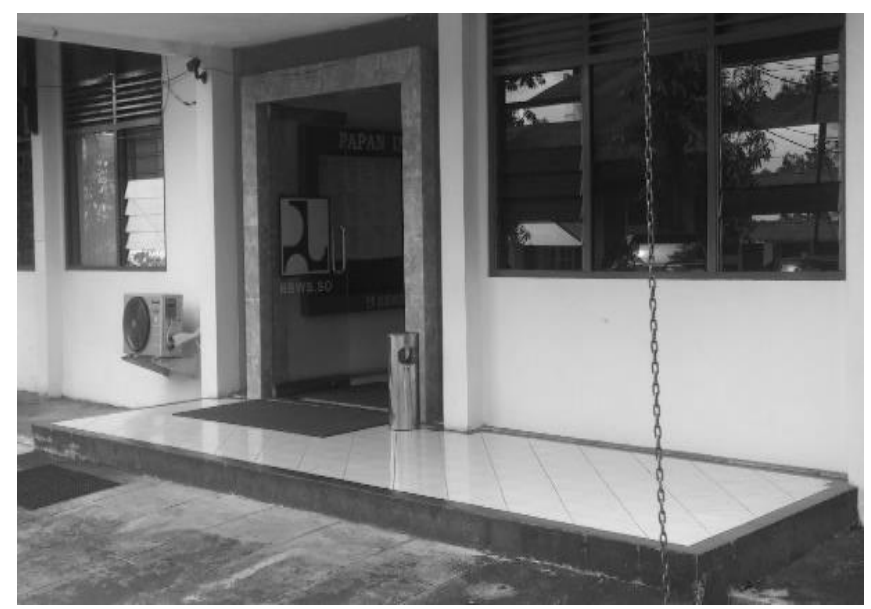

Figure 6. The steps at the entrance of Serayu Opak River Basin Organization (SORBO) building.

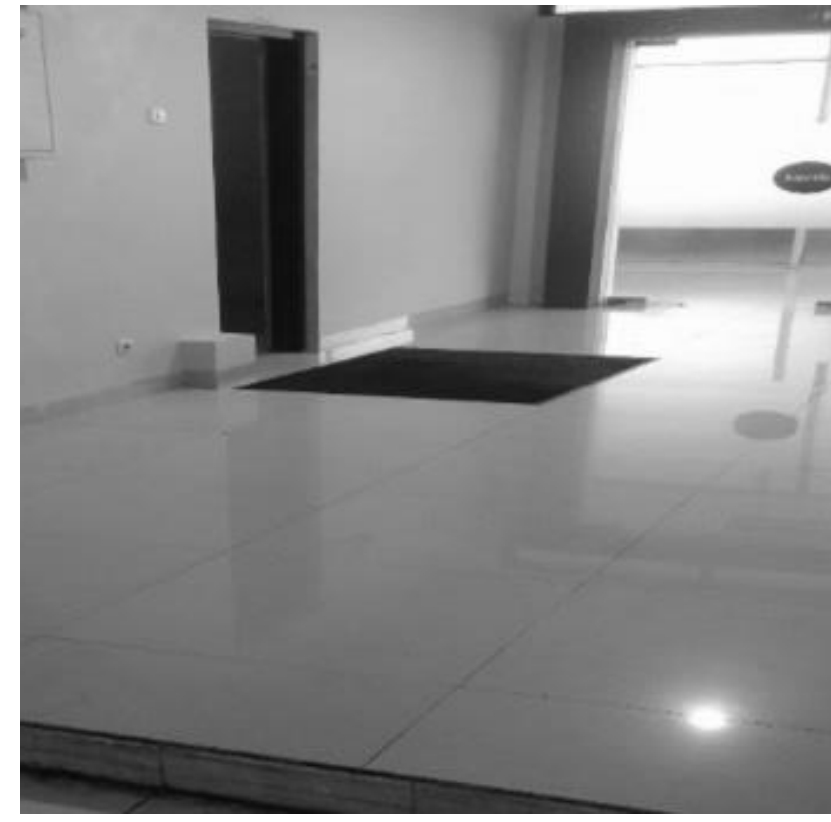

Figure 7. The steps at the entrance of Serayu Opak River Basin Organization (SORBO) toilet.

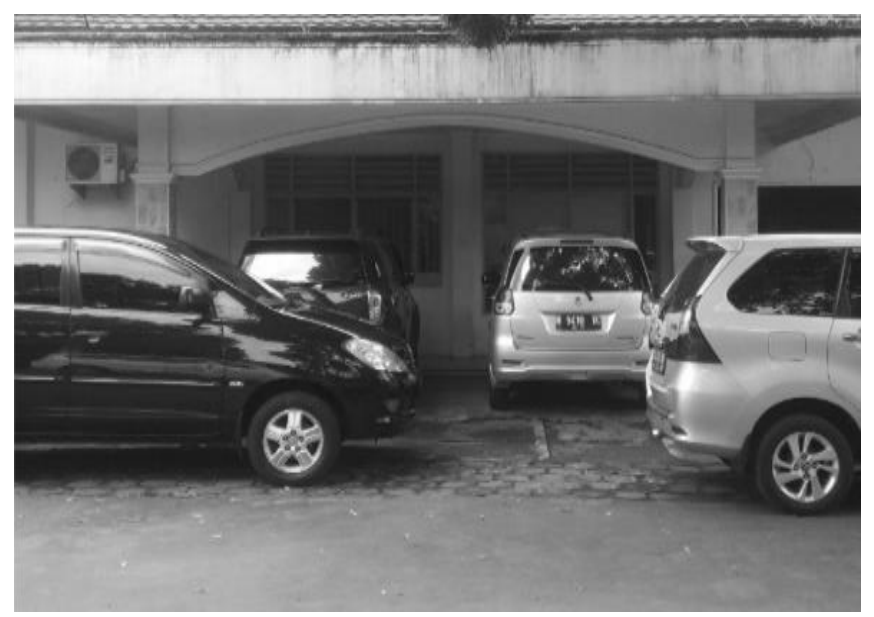

Figure 8. Access to the entrance of PKSDA building blocked by vehicles.

Table 1. The completeness of public toilets facilities in Serayu Opak River Basin Organization (SORBO) building, PKSDA building, PJSA and Water Resources Field (WRF) building, and Water Resources Management Center (WRMC) building

\begin{tabular}{|c|c|c|c|c|c|c|c|c|c|c|c|}
\hline \multirow[b]{2}{*}{ Buildings } & \multicolumn{11}{|c|}{ Toilet Facilities } \\
\hline & $\begin{array}{l}\text { Man } \\
\text { Bathroom }\end{array}$ & $\begin{array}{l}\text { Woman } \\
\text { Bathroom }\end{array}$ & $\begin{array}{l}\text { Disability } \\
\text { Bathroom }\end{array}$ & WC & $\begin{array}{l}\text { Water } \\
\text { Container }\end{array}$ & Scoop & Spigot & $\begin{array}{l}\text { Trash } \\
\text { Can }\end{array}$ & Urinal & Sink & Mirror \\
\hline SORBO & 2 & 2 & - & $\mathrm{v}$ & $\mathrm{V}$ & $\mathrm{V}$ & $\mathrm{V}$ & $\mathrm{V}$ & - & $\mathrm{V}$ & $\mathrm{V}$ \\
\hline $\begin{array}{l}\text { PJSA \& } \\
\text { WRF }\end{array}$ & 1 & 2 & - & $\mathrm{v}$ & $\mathrm{v}$ & $\mathrm{v}$ & $\mathrm{v}$ & - & $\mathrm{v}$ & - & $\mathrm{v}$ \\
\hline PKSDA & 5 & 5 & - & $\mathrm{v}$ & - & - & $\mathrm{v}$ & $\mathrm{v}$ & - & $\mathrm{v}$ & $\mathrm{v}$ \\
\hline WRMC & 2 & 2 & - & $\mathrm{v}$ & $\mathrm{v}$ & $\mathrm{v}$ & $\mathrm{v}$ & $\mathrm{v}$ & - & $\mathrm{v}$ & $\mathrm{v}$ \\
\hline
\end{tabular}




\subsubsection{Inaccuracy of Rescue Facility Design}

a) The corridor design is less wide

The corridor of Serayu Opak River Basin Organization (SORBO) building area has only $1.7 \mathrm{~m}$ width (Figure 9). Not in accordance with the Regulation of the Minister of Public Works No. 45 / PRT / M / 2007 Year 2007 on Technical Guidelines Development of the State House which requires a minimum width of $1.8 \mathrm{~m}$ net corridor.

\subsubsection{Inaccuracy of Rescue Facility Design \\ b) The corridor design is less wide}

The corridor of Serayu Opak River Basin Organization (SORBO) building area has only $1.7 \mathrm{~m}$ width (Figure 9). Not in accordance with the Regulation of the Minister of Public Works No. 45 / PRT / M / 2007 Year 2007 on Technical Guidelines Development of the State House which requires a minimum width of $1.8 \mathrm{~m}$ net corridor.

c) Stair design is less wide

Residential building/building consisting of 2 floors or more, the size of the stairs used has a minimum width of $125 \mathrm{~cm}$. However, the staircase in the Water Resources Management Office building is only $85 \mathrm{~cm}$ wide as can be seen in Figure 10.

d) No emergency lighting and a signpost EXIT

All buildings located in the institutions of Serayu Opak River Basin Organization (SORBO), PKSDA, PJSA and Water Resources Field (WRF), and Water Resources Management Center (WRMC) have no emergency lighting and EXIT signposts. The staircase and corridors that are not in accordance with the provisions and without being equipped with emergency lighting and signposts EXIT will complicate the evacuation in case of an emergency.

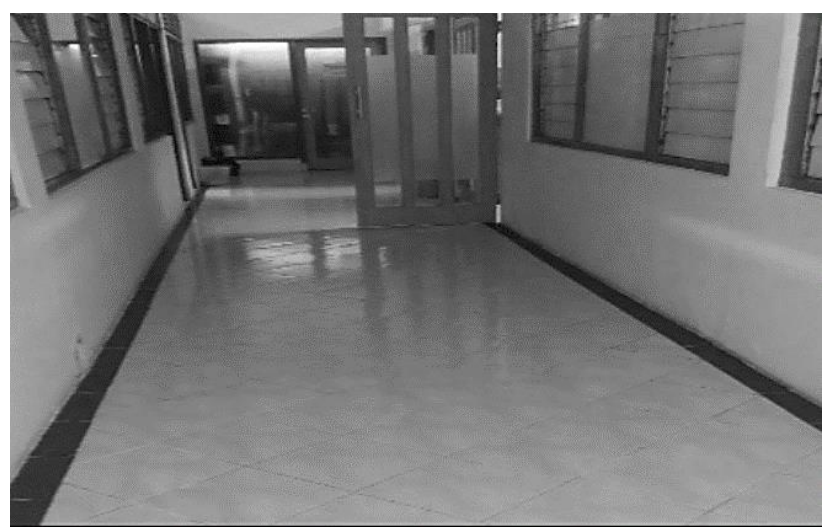

Figure 9. The corridor of Serayu Opak River Basin Organization (SORBO) building.

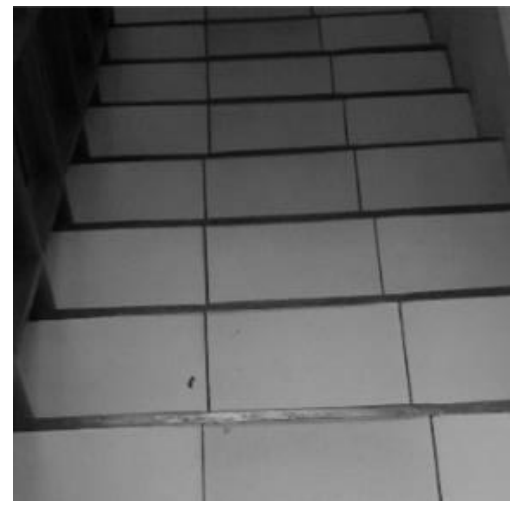

Figure 10. Stair in Water Resources Management Building.

\subsection{Building Maintenance Cost Analysis}

Building maintenance cost analysis aims to determine whether the required maintenance budget in accordance with the available budget. Building maintenance cost analysis can be seen in Table 2. It shows that the required maintenance budget of the building is the same as the available maintenance budget of the building except for the agency of Water Resources Field because the agency shares the same building with PJSA agency, so that if there is damage to building components, PPK Ketatalaksanaan from Serayu Opak River Basin Organization agency will repair it. Besides that, the budget for maintenance of Serayu Opak River Basin Organization (SORBO) and PKSDA building in 2012 are in shortage. This is due to budget cuts by the Central Government.

\subsection{The Influence of Building Design Inaccuracy against Maintenance Costs}

Based on the previous analysis, there are 5 building design inaccuracies. However, due to limited budget maintenance, the building manager cannot fix all the design's inaccuracy. Building managers should prioritize to correct some of the design's inaccuracies first. The priority is to reduce heat and glare in the room. This is because the heat and glare directly affect the comfort of employees in the room. The way to reduce heat and glare in the room is by installing air conditioners and a barrier of sunlight. The amount of cost used to install the air conditioner and the barrier of sunlight can be seen in Table 3 .

The total overall maintenance budget used to reduce heat and glare indoors from 2012 to 2016 is $43,529,082$ IDR. From these results, it can be concluded that the office building design of Serayu Opak River Basin Organization (SORBO), PKSDA, PJSA and Water Resources Field (WRF), and Water Resources Management Center (WRMC) does not meet the requirements and regulations of the applicable regulations. 
Vol. 3 No. 3 (September 2017)

Table 2. The comparison between the amount of maintenance budget required and the amount of maintenance budget available 2012 - 2016

\begin{tabular}{|c|c|c|c|c|c|c|c|c|c|c|}
\hline \multirow{2}{*}{ Buildings } & \multicolumn{5}{|c|}{ Budget Amount Required (x1000 IDR) } & \multicolumn{5}{|c|}{ Budget Amount Available (x1000 IDR) } \\
\hline & 2012 & 2013 & 2014 & 2015 & 2016 & 2012 & 2013 & 2014 & 2015 & 2016 \\
\hline SORBO & 80.155 & 98.974 & 98.974 & 105.247 & 105.247 & 64.135 & 98.974 & 98.974 & 105.247 & 105.247 \\
\hline PKSDA & 118.560 & 120.042 & 121.524 & 128.934 & 128.934 & 78.000 & $120.041,6$ & 121.524 & 128.934 & 128.934 \\
\hline PJSA & 48.640 & 49.248 & 49.856 & 52.896 & 52.896 & $50.081,1$ & 49.248 & 49.856 & 52.896 & 52.896 \\
\hline WRF & 45.040 & 45.603 & 46.166 & 48.981 & 48.981 & - & - & - & - & - \\
\hline WRMC & 77.510 & 95.708 & 95.708 & 101.774 & 101.774 & 94.250 & 95.708 & 95.708 & 101.774 & 101.774 \\
\hline
\end{tabular}

Table 3. Recapitulation of building maintenance cost of Serayu Opak River Basin Organization (SORBO), PKSDA, PJSA and Water Resources Field (WRF), and Water Resources Management Center (WRMC) which is used to reduce heat and glare indoors from 2012 - 2016

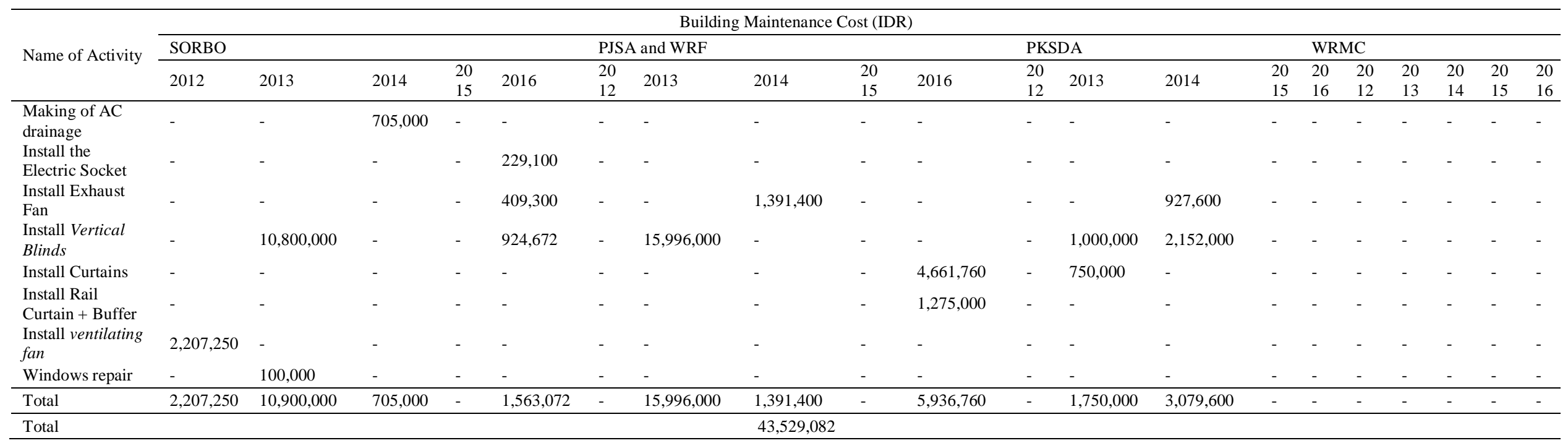




\section{CONCLUSIONS}

Based on this research, there are several findings as follows:

a) There are less suitable building design, i.e. working room employees, the gutter design of the Serayu Opak River Basin Organization (SORBO) building, the location, room size and completeness of toilet facilities, accessibility design, the corridor in Serayu Opak River Basin Organization (SORBO), and staircase of Water Resource Management Office building.

b) The required budget for the building maintenance of Serayu Opak River Basin Organization (SORBO), PKSDA, PJSA and Water Resources Field (WRF), and Water Resources Management Center (WRMC) equal to the available budget.

a) The effect of the inaccuracy design against building maintenance cost is the presence of jobs to install air conditioning equipment and a barrier of sunlight, which source of funds comes from building maintenance budget.

b) The design of Serayu Opak River Basin Organization (SORBO), PKSDA, PJSA and Water Resources Field (WRF), and Water Resources Management Center (WRMC) buildings are not in compliance with the terms and conditions of the applicable regulations.

\section{RECOMMENDATIONS}

The following are some recommendations for the further research:

a) Renovate the roof and side of the building by installing a heat insulator on the roof and coated glass with clear film glass.

b) Replace/redesign the gutter by adding a vertical pipe to the outlet pipe (funnel) to allow rainwater to enter fully into the drain.

c) Equip toilets with facilities in accordance with Indonesian Public Toilet Standards.

d) Increase access for people with disabilities.

e) Install the alarm for emergency situations so that the evacuation process can be done earlier and faster.

f) Make clear signs and parking limits.

\section{REFERENCES}

Astuti, A. D., 2017. Ultraviolet Absorption

Measurement on Film Glass Using UVM-30A Sensor

Based Microcontroller ATMEGA8535, Lampung:
Department of Physics Faculty of Mathematics and Natural Sciences University of Lampung.

Directorate General of Land Transportation, 1998. Guidelines for Planning and Operation of Parking Facility, Jakarta: Government of the Republic of Indonesia.

Ervianto, 2007. Building Maintenance Study (Case Study of Campus Building). Journal of Civil Engineering Atma Jaya University Yogyakarta, 7(3).

Government of the Republic of Indonesia, 2005.

Government Regulation Number 36 Year 2005

regarding the Implementation of Law Number $28 \underline{\text { Year }}$ 2002 regarding Building, Jakarta.

Hersanto, M.P., 2017. Suitability Analysis of Office Building Design against Maintenance Cost (Case Study: Institution of Serayu Opak River Basin Organization, Water Resources Field and Management Center in Yogyakarta Special Region), Yogyakarta: Master Thesis, Department of Civil and Environmental Engineering, Faculty of Engineering, Universitas Gadjah Mada.

Melati, I., 2015. Understand About Roof Insulation Materials. [Online]

Available at: http://ataprumahjakarta.blogspot.co.uk/2015/12/meng enal-material-insulasi-atap.html

[Accessed 6 June 2017].

Ministry of Culture and Tourism, 2004. Indonesian Public Toilet Standards, Jakarta: Government of the Republic of Indonesia.

Ministry of Finance, 2011. Regulation of the Minister of Finance Number 84 / PMK.02 / 2013 on Standard Cost Input of Fiscal Year 2012, Jakarta: Government of the Republic of Indonesia.

Ministry of Finance, 2012. Regulation of the Minister of Finance No. 37 / PMK.02 / 2014 on Standard Cost Input of Fiscal Year 2013, Jakarta: Government of the Republic of Indonesia.

Ministry of Finance, 2013. Regulation of the Minister of Finance Number 72 / PMK.02 / 2013 on Standard Cost Input of Fiscal Year 2014, Jakarta: Government of the Republic of Indonesia. 
Ministry of Finance, 2014. Regulation of the Minister of Finance No. 53 / PMK.02 / 2014 on Standard Cost Input of Fiscal Year 2015, Jakarta: Government of the Republic of Indonesia.

Ministry of Finance, 2015. Regulation of the Minister of Finance No. 65 / PMK.02 / 2015 on Standard Cost Input of Fiscal Year 2016, Jakarta: Government of the Republic of Indonesia.

Ministry of Public Works, 2007. Regulation of the Minister of Public Works No. 45 / PRT / M / 2007 Year 2007 on Technical Guidance of State Building
Construction, Jakarta: Government of the Republic of Indonesia.

Neufert, E., 1996. Data Architects Volume I. 33th

Edition ed. Jakarta: Erlangga.

Neufert, E., 2002. Data Architects Volume II. Jakarta: Erlangga.

Soegijanto, 1998. Building in Indonesia with Tropical Climate Humidity in terms of Physical Aspects of Building, Bandung: Directorate General of Higher Education Department of Education and Culture. 